J Arid Land (2014) 6(3): 300-310

doi: $10.1007 / \mathrm{s} 40333-013-0199-2$

jal.xjegi.com; www.springer.com/40333

\title{
Soil water repellency and influencing factors of Nitraria tangutorun nebkhas at different succession stages
}

\author{
HaoTian YANG, XinRong LI, LiChao LIU*, YanHong GAO, Gang LI, RongLiang JIA \\ Shapotou Desert Research and Experiment Station, Cold and Arid Regions Environmental and Engineering Research Institute, Chinese \\ Academy of Sciences, Lanzhou 730000, China
}

\begin{abstract}
Soil water repellency (WR) is an important physical characteristic of soil surface. It is capable of largely influencing the hydrological and geomorphological processes of soil, as well as affecting the ecological processes of plants, such as growth and seed germination, and has thus been a hot topic in recent research around the world. In this paper, the capillary rise method was used to study the soil WR characteristics of Nitraria tangutorun nebkhas. Soil water repellencies at different succession stages of Nitraria tangutorun were investigated, and the relationships between soil WR and soil organic matter, total $\mathrm{N}$, and total $\mathrm{P}$, soil texture, $\mathrm{pH}$, and concentrations of $\mathrm{CO}_{3}{ }^{2-}, \mathrm{HCO}_{3}$, $\mathrm{Cl}^{-}, \mathrm{SO}_{4}{ }^{2-}, \mathrm{Na}^{+}, \mathrm{K}^{+}, \mathrm{Ca}^{2+}$ and $\mathrm{Mg}^{2+}$ were discussed. Soil WR may be demonstrated at the following nebkhas dune evolvement stages: extremely degraded>degraded>stabilized>well developed>newly developed>quick sand. Apart from some soil at the bottom, the WR of other soils (crest and slope of dune) was found to be largest at the topsoil, and decreased as the soil depth increased. The results showed that multiple factors affected soil WR characteristics, e.g. WR increased significantly as the contents of soil organic matter and total $\mathrm{N}$ increased, but did not change as the total P content increased. Soil texture was a key factor affecting soil WR; soil WR increased significantly as clay content increased, and decreased significantly as sand content increased. Low pH was shown to be more suitable for the occurrence of soil WR. Four cations $\left(\mathrm{Ca}^{2+}, \mathrm{Mg}^{2+}, \mathrm{K}^{+}\right.$and $\left.\mathrm{Na}^{+}\right)$and two anions $\left(\mathrm{Cl}^{-}\right.$and $\left.\mathrm{SO}_{4}{ }^{2-}\right)$ enhanced soil WR, while $\mathrm{CO}_{3}{ }^{2-}$ decreased it. $\mathrm{HCO}_{3}{ }^{-}$did not show any observable effect. Finally, we established a best-fit general linear model (GLM) between soil-air-water contact angle (CA) and influencing factors (CA $=5.606$ sand +6.496 (clay and silt)-2.353 pH+470.089 $\mathrm{CO}_{3}{ }^{2+}+11.346 \mathrm{Na}^{+}-407.707 \mathrm{Cl}^{-}-14.245 \mathrm{SO}_{4}{ }^{2-}+0.734$ total $\left.\mathrm{N}-519.521\right)$. It was concluded that all soils contain subcritical WR $\left(0^{\circ}<\mathrm{CA}<90^{\circ}\right)$. The development and succession of Nitraria tangutorun nebkhas may improve the formation of soil subcritical WR. There exist significant relationships between soils subcritical WR and soil physical or chemical properties.
\end{abstract}

Keywords: hydrophobicity; soil-air-water contact angle; capillary rise method; Nitraria tangutorun nebkhas; vegetation succession stage

Citation: HaoTian YANG, XinRong LI, LiChao LIU, YanHong GAO, Gang LI, RongLiang JIA. 2014. Soil water repellency and influencing factors of Nitraria tangutorun nebkhas at different succession stages. Journal of Arid Land, 6(3): 300-310. doi: 10.1007/s40333-013-0199-2

Water repellency (WR) is a fundamental physical property of soils. The term refers to the ability to reduce the affinity of soils to water where water entry is resisted or inhibited (Doerr et al., 2000; Blanco and Lal, 2009). The degree of WR may be quantified by the soil-air-water contact angle (CA), which is measurable at the three-phase boundary (i.e. the boundary among the gas, liquid and solid phases; Letey, 1969).
In general, a soil surface exhibiting a $\mathrm{CA}=0^{\circ}$ is considered to be hydrophilic (Siebold et al., 1997). CA in the soil surface below $90^{\circ}$ represents a subcritical water repellency (slight WR but non-hydrophobic) (Morrow, 1976; Yang and Xi, 1995; Siebold et al., 1997; Shirtcliffe, 2006). When CA $>90^{\circ}$, the soils possess an extreme or severe water repellency (DeBano, 2000a; Doerr et al., 2007). Almost all soils show a

\footnotetext{
"Corresponding author: LiChao LIU (E-mail: lichao@lzb.ac.cn) Received 2013-04-22; revised 2013-06-26; accepted 2013-07-29

(c) Xinjiang Institute of Ecology and Geography, Chinese Academy of Sciences, Science Press and Springer-Verlag Berlin Heidelberg 2014
} 
certain degree of WR (Wallis and Horne, 1992; Doerr et al., 2000; Jordán et al., 2013).

WR is a widespread phenomenon and recognized as a severe problem in many parts of the world (Wallis and Horne, 1992). WR has been reported to occur in a range of regions, climates, soil types, vegetation covers and land uses (Wallis and Horne, 1992; DeBano, 2000a; Doerr et al., 2000; Jaramillo et al., 2000; Mataix-Solera and Doerr, 2004; Dekker et al., 2005; Doerr et al., 2005; Mataix-Solera et al., 2007). For instance, water repellent soils have been identified in the USA (Steenhuis et al., 2001; Park et al., 2004), Canada (Quyum, 2001), Australia (Cann, 2000; McKissock, 2003), New Zealand (Horne and McIntosh, 2000), and many other countries and regions (Dekker et al., 2005). WR has also been observed to occur in soils under both coniferous and deciduous trees (Mataix-Solera and Doerr, 2004; Lewis et al., 2006; Jordán et al., 2008), temperate heathlands (Mallik and Rahman, 1985), Mediterranean shrublands (Mataix-Solera et al., 2007; Jordán et al., 2008) and grasslands (Berglund and Persson, 1996).

Soil WR has a significant effect on ecological and hydrologic processes in many ecological systems, especially in arid areas (Doerr et al., 2000). Soil WR may modify the redistribution of surface and subsurface water by reducing soil infiltration rates, increasing runoff, inducing preferential flow paths, and changing the spatial variability of soil moisture distribution. Soil moisture redistribution has key implications for the water uptake of plant root systems, therefore soil WR may have a major repercussion for plant growth, and may also have an impact on the re-establishment (re-distribution) of vegetation, due to the reduction of water availability and redistribution of soil nutrients (Dekker and Ritsema, 1994; Ritsema and Dekker, 1994, 1998, 2000; Bauters et al., 1998; DeBano, 2000; McLeod et al., 2001; Mataix-Solera et al., 2007; Jordán et al., 2008; Martínez-Zavala and Jordán López, 2009). In addition, soil WR may modify many soil properties, such as the water retention curve and soil aggregation (Blanco et al., 2007; Czachor et al., 2010; Mataix-Solera et al., 2011), and may also enhance erosion risk (Doerr et al., 2000). The importance of these effects mainly depends upon the degree and spatial variability of the soil WR (Ritsema and Dekker, 1994).
Despite the significance of soil WR to a wide range of hydrologic, geomorphological and ecological processes, the degree of this property and its relationships with other soil properties (e.g. soil organic carbon, particle size distribution, soil $\mathrm{pH}$, soluble ions, etc) in the arid desertified grasslands in western China have not yet been comprehensively investigated. The Minqin Oasis once acted as a natural barrier between the Badain Jaran Desert and Tengger Desert in western China. It is also one of the four major sources of sandstorms in northern China, continuously resulting in severe ecological problems. Local monitoring showed that the degree of desertification in this area was degraded from mild to severe/very severe by the end of the $20^{\text {th }}$ century (Shi, 2000). As a typical desert plant species in the oasis-desert transitional zone of Minqin, Nitraria tangutorun nebkhas is an effective preventer of desertification. The pattern of the vegetation structure in Minqin has been documented as the occurrence of vegetation patches within large patches of bare soil, similar to the case in most arid and semi-arid regions of the world. One of the most important features in patchy or banded vegetation types in arid and semi-arid regions is that the bare soil patches among vegetation clumps are considered to be the runoff generation or source areas, and the vegetation-covered areas are considered to be water-adsorbing patches or sink areas (Li et al., 2008). Soil WR may play an important role in controlling the distribution of limited water resources in this area, which in turn may affect soil water use and growth of plants, and therefore affect vegetation succession.

On the basis of the above mentioned important aspects, it is necessary to examine WR in desert soils to specifically clarify the effects of vegetation (Nitraria tangutorun), as well as the effect of vegetation succession on WR. In addition, it is also important to study the relationship between WR and other soil properties (e.g. soil organic carbon, particle size distribution, soil $\mathrm{pH}$ and soluble ions), in order to more accurately predict soil WR in arid decertified grassland environments. The authors of this paper hypothesize that soil WR varies with vegetation succession and may thus have impacts on the local eco-hydrological processes. The objectives of this study are: (a) to examine the degree of WR in soil samples under plants of Nitraria tangutorun nebkhas at its different evolvement stages, 
and (b) to examine the effects of other soil properties such as soil organic carbon, total nitrogen, total phosphorus, particle size distribution, soil $\mathrm{pH}$, and soluble ions on WR.

\section{Materials and methods}

\subsection{Study area}

The study area $\left(101^{\circ} 59^{\prime}-104^{\circ} 12^{\prime} \mathrm{E}, 38^{\circ} 08^{\prime}-39^{\circ} 26^{\prime} \mathrm{N}\right.$; $1,311-1,378.5 \mathrm{~m}$ asl) is located in the downstream of the Shiyang River, at the leading edge intersection of the Tengger and Badan Jilin deserts, and is a typical oasis-desertification region. The area includes Qingtu Lake, Shajingzi, and Sanjiao town, and is surrounded by the Tengger and Badan Jilin deserts in the east, west, and north. According to the meteorological data from the Weather Bureau in Minqin county, the area is characterized by a typical continental arid climate, with an annual average temperature of $7.6^{\circ} \mathrm{C}$. The average annual precipitation is $113.2 \mathrm{~mm}$; the annual potential evaporation is as high as $2,604.3 \mathrm{~mm}$; and the annual average number of days with sandstorms is 25.6. In the $1950 \mathrm{~s}$, seasonal lakes appeared in the low-lying region of the Minqin Basin, and the groundwater level was 1-3 m; however, it has since fallen to below $23 \mathrm{~m}$ in 2006 (Han et al., 2008).

Oasis peripheries in the area consist mainly of alluvial plains with sand soil. Natural vegetation consists mainly of Nitraria tangutorum plants, which mostly exist in the form of $0.5-3.0 \mathrm{~m}$ high nebkhas. $\mathrm{Ni}$ traria tangutorum is a typical desert plant, forming the local climax community. Other species include Tamarix laxa, Calligonum mongolicum, Halogeton arachnoideus, etc. Nitraria tangutorum nebkhas enables the formation of the landscape pattern with al- ternatively distributed strips of sand lowland and nebkhas, and effectively prevents peripheral mobile sand dune erosion from reaching the oasis.

\subsection{Sample collection}

Soil samples were collected from the natural vegetation area of oasis-desert transitional zone in Minqin in May 2010. Samples of mobile sand dune (control) and Nitraria tangutorun nebkhas at five different succession stages (i.e. newly developed, well developed, stabilized, degraded and extremely degraded) (Table 1) were selected. At each stage, samples were taken from three typical nebkhas with similar shape, size, vegetation cover, crust development degree. Soil samples (at 0-5, 5-10 and 10-20 cm depths) were collected at different parts of the nebkhas (crest, slope, and bottom). At each part (crest, slope, and bottom), four sites were selected in the east, west, south and north, respectively. At each site, three soil samples were collected and mixed for reducing soil spatial heterogeneity.

\subsection{Soil analysis}

Each soil sample was divided into two parts after mixing. One part was dried at $25^{\circ} \mathrm{C}$ to a constant weight and sieved $(<2 \mathrm{~mm})$ to eliminate coarse soil particles. Those samples were used to measure soil water repellency, and soil acidity $(\mathrm{pH})$ was measured in aqueous soil extract in de-ionised water $(1: 2.5$ soil:water). The other part was air dried and sieved $(<2$ $\mathrm{mm}$ ) for measuring soil organic carbon, total $\mathrm{N}$, total $\mathrm{P}$, soil particle composition, ions of potassium, sodium, calcium, magnesium, sulfate, carbonate, bicarbonate, and chloride-soluble salt. Soil organic matter was determined by the Walkley-Black method

Table 1 Characteristics of Nitraria tangutorun nebkhas

\begin{tabular}{|c|c|c|}
\hline Type & Succession stage & Nitraria tangutorun nebkhas characteristics \\
\hline A & Extremely degraded & $\begin{array}{l}\text { Nitraria was fully degraded. There was a well-developed biological soil crust. The small amount of } \\
\text { annual herbaceous and perennial shrubs exists in the seedling stage, and vegetation cover is less } \\
\text { than } 5 \% \text {. }\end{array}$ \\
\hline $\mathrm{B}$ & Degraded & Good growth of Nitraria, Phragmites communis nearby, with little sand sheet, vegetation cover is $70 \%$. \\
\hline $\mathrm{C}$ & Stabilized & $\begin{array}{l}\text { Phragmites communis grows between Nitraria tangutorun nebkhas, with relatively good growth of } \\
\text { nitraria, vegetation cover is } 70 \% \text {. }\end{array}$ \\
\hline $\mathrm{D}$ & Well developed & No crust coverage, nitraria cover is about $30 \%$; lowland between dunes is lacustrine and sturdy. \\
\hline $\mathrm{E}$ & Newly developed & $\begin{array}{l}\text { Twenty meters far from mobile sand dune (significantly distant), no biological soil crust, small amount } \\
\text { of Agriophyllum squarrosum, Limonium aureum, and Pugionium cornutum, vegetation cover is } 20 \% \text {. }\end{array}$ \\
\hline $\mathrm{F}$ & $\begin{array}{l}\text { Immature } \\
\text { (mobile sand dune) }\end{array}$ & No vegetation or vegetation cover is less than $1 \%$. \\
\hline
\end{tabular}


(Walkley and Black, 1934). Total nitrogen was measured by the Regular Macro-Kjeldahl method. Particle size distribution $(2-0.05 \mathrm{~mm}$, sand; $0.05-0.002 \mathrm{~mm}$, silt; $<0.002 \mathrm{~mm}$, clay) was determined by a laser particle size analyzer (MS-S, British Malvem instrument, UK). Total phosphorus (TP) was analyzed through perchloric acid-sulfuric acid digestion-Mo-Sb colorimetry (Parkinson and Allen, 1975). Sodium and potassium ions were analyzed through flame photometry (Barnes et al., 1945). Calcium and magnesium ions were determined by EDTA titration (Hadjiioannou and Papastathopoulous, 1970). Chloride ion was determined by silver nitrate titration. Carbonate and bicarbonate ions were determined by the double indicator titration method, and the Ion Chromatographic method was used for determining $\mathrm{SO}_{4}{ }^{2-}$ in soils (Dick and Tabatabai, 1979).

\subsection{Contact angle of soil}

In this study, CA was determined by the Capillary Rise Method (CRM), which is in theory ranging from $0^{\circ}$ to $90^{\circ}$. This method is an effective indirect method and suitable for this study. The soil samples were placed in a glass tube (10 $\mathrm{mm}$ in diameter) with a sintered bottom (Ramírez-Flores et al., 2008). The packing density was controlled by the mass (about $35 \mathrm{~g}$ ) and height $(25 \mathrm{~cm})$ of the soil in the glass tube, which was filled uniformly. The glass tube was then lowered until the sintered glass bottom immerged into the liquid. The length of the wetting-front and the change of the sample weight $(\mathrm{w})$ were recorded until the final height was reached. During the experiment, the laboratory temperature and relative humidity were $20^{\circ} \mathrm{C}$ and 50\%, respectively (Siebold et al., 1997; RamírezFlores et al., 2008; Cosentino et al., 2010).

The CA $\left(\theta^{\circ}\right)$ is calculated on the basis of the Washburn equation:

$$
h^{2}=\frac{r \gamma \cos \theta}{2 \eta} t .
$$

Where $h$ represents the liquid-penetration length (m) of the wetting-front; $r$, the effective radius of the capillary, expressing the idealized pore system of granular material $(\mathrm{m}) ; \gamma$, the surface tension of the test liquid $\left(\mathrm{J} / \mathrm{m}^{2}\right) ; \eta$, the viscosity of the test liquid (Pa.s); $t$ time (s); and $\theta$, the CA between soil and liquid (Siebold et al., 1997).

In general, the increase of the sample weight $(w)$ is more accurate and easier to measure than the visual evaluation of the height of the wetting front. The soil weight $(w)$ can be measured and automaticlly recorded by using a sensitive microbalance connected to a computer (Siebold et al., 1997). Equation 1 then becomes a modified Lucas-Washburn equation:

$$
w^{2}=K \frac{\rho^{2} \gamma \cos \theta}{2 \eta} t
$$

Where $w$ is the mass of the absorbed liquid $(\mathrm{kg}), K$ is an empirical constant summarizing property of the pore system, which depends on particle size and degree of packing $\left(\mathrm{m}^{5}\right)$. The parameters $\rho, \gamma$ and $\eta$ are the density $\left(\mathrm{kg} / \mathrm{m}^{3}\right)$, surface tension $\left(\mathrm{J} / \mathrm{m}^{2}\right)$ and viscosity (Pa.s) of the test liquid, respectively. $\theta$ is the CA between the solid and liquid.

The values of $h$ and $w$ are determined respectively with distilled water and n-octane. $\mathrm{N}$-octane is a type of entirely wettable liquid with a $\mathrm{CA}=0^{\circ}$ was used to estimate $r$ in the Washburn Eq. 1 and $K$ in Eq. 2. When determining either $r$ or $K$, the CA using distilled water can be calculated using the same equation (Siebold et al., 1997; Ramírez-Flores et al., 2008; Cosentino et al., 2010; Ramírez-Flores et al., 2010).

\subsection{Data analysis}

SPSS 16.0 was used for statistical analysis. Tests of normal distribution and Chi-square were used to test the data. One-way ANOVA was used to analyze the differences between the succession stages of Nitraria tangutorun nebkhas, as well as between soil layers, and Tukey's test was used for multiple comparisons. R-Spearman correlations and Linear regression analysis were applied for correlation analysis between CA and influencing factors (soil organic matter, total $\mathrm{N}$, total $\mathrm{P}$, soil texture, $\mathrm{pH}$, and concentrations of $\mathrm{CO}_{3}{ }^{2-}$, $\mathrm{HCO}_{3}{ }^{-}, \mathrm{Cl}^{-}, \mathrm{SO}_{4}{ }^{2-}, \mathrm{Na}^{+}, \mathrm{K}^{+}, \mathrm{Ca}^{2+}$ and $\left.\mathrm{Mg}^{2+}\right)$. At last, a general linear model (GLM) was used to describe the integrative effects of main influencing factors on CA.

\section{Results}

\subsection{Soil water repellency characteristics}

Figure 1 shows the respective CA on the dune crest, slope and interdune land at different succession stages. Overall, the CA at stages A, B, C and D are significantly greater than those of newly developed dune and mobile sand dune $(P<0.001)$ for all three parts. On the 

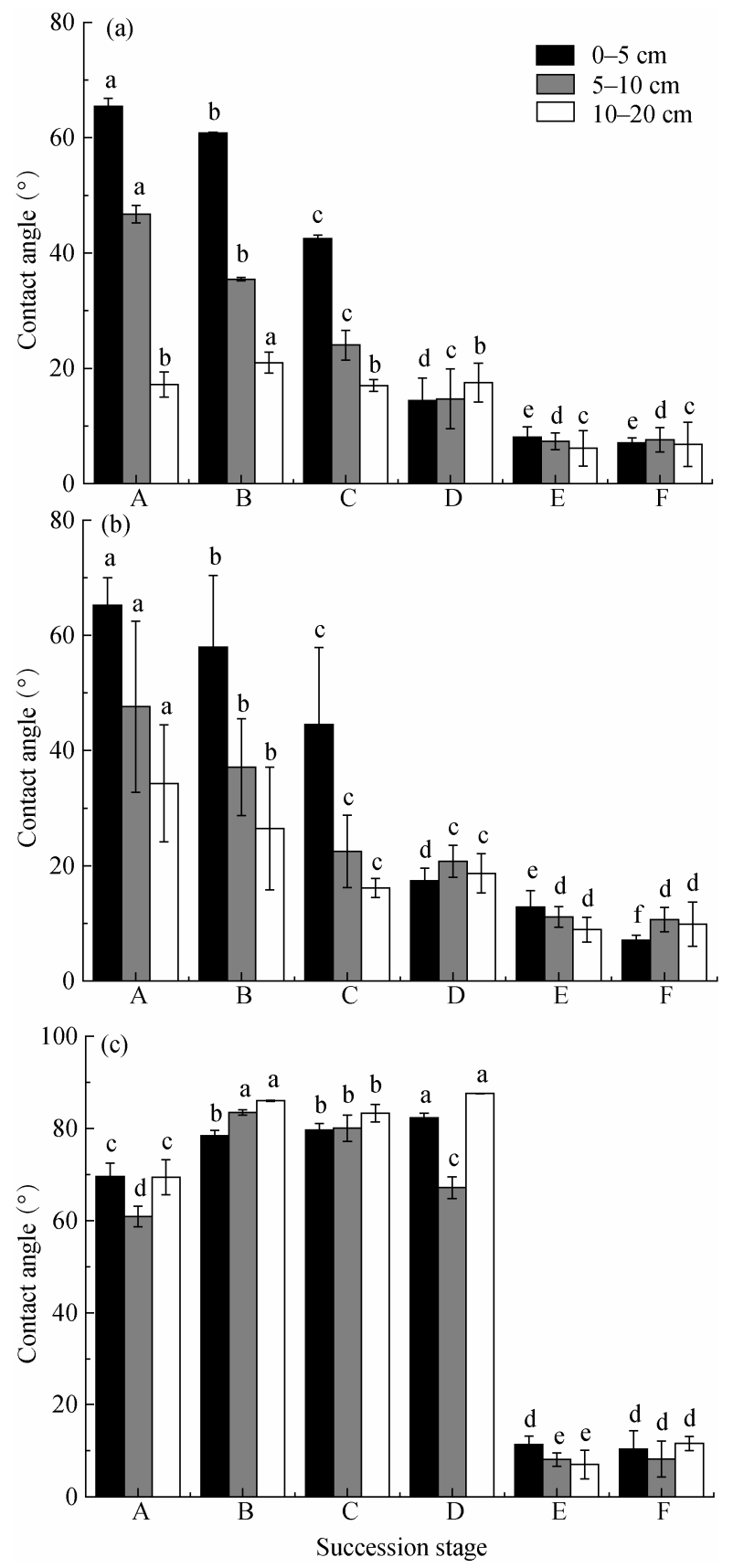

Fig. 1 Soil water repellency characteristics of Nitraria tangutorun nebkhas at different succession stages. (a), (b) and (c) are the crest, slope and bottom of the Nitraria tangutorun nebkhas, respectively. A represents the extremely degraded stage; $\mathrm{B}$, degraded stage; C, stabilized stage; D, well developed stage; E, newly developed stage; and $\mathrm{F}$, mobile sand dune.

dune crest, for the $0-5$ and 5-10 $\mathrm{cm}$ soil layers, CA were significantly different among stages $\mathrm{A}, \mathrm{B}, \mathrm{C}$ and D $(A>B>C>D)$; for the $10-20 \mathrm{~cm}$ soil layer, $C A$ at $B$ stage was significantly greater than that at stages $A$, $\mathrm{C}$, and $\mathrm{D}$, with no significant difference among stages
$A, C$, and $D(B>D>A>C)$. On the dune slope, for the $0-5 \mathrm{~cm}$ soil layer, the $\mathrm{CA}$ among stages $\mathrm{A}, \mathrm{B}, \mathrm{C}$ and $D$ were significantly different $(A>B>C>D)$; for the $5-$ $10 \mathrm{~cm}$ layer, the CA among stages $\mathrm{A}, \mathrm{B}, \mathrm{C}$ or $\mathrm{A}, \mathrm{B}, \mathrm{D}$ were significantly different, but the difference between stages $C$ and $D$ was not significant $(A>B>C>D)$. At the bottom, for the $0-5 \mathrm{~cm}$ soil layer, the $\mathrm{CA}$ among stages $\mathrm{D}, \mathrm{C}$, and $\mathrm{A}$ and among $\mathrm{D}, \mathrm{B}$, and A were significantly different, but the difference between $\mathrm{B}$ and $C$ was not significant $(D>C>B>A)$; for the $5-10 \mathrm{~cm}$ layer, the $C A$ among $A, B, C$, and $D$ were significantly different $(B>C>D>A)$; for the 10-20 cm soil layer, the $\mathrm{CA}$ among stages $\mathrm{A}, \mathrm{C}$, and $\mathrm{D}$ and $\mathrm{A}, \mathrm{B}$, and $\mathrm{C}$ were significantly different, but the difference between $B$ and $\mathrm{D}$ was not significant $(\mathrm{D}>\mathrm{B}>\mathrm{C}>\mathrm{A})$. The $\mathrm{CA}$ differed at different soil layers. On the dune crest and slope, $\mathrm{CA}$ among stages $\mathrm{A}, \mathrm{B}$, and $\mathrm{C}$ were significantly different $(P<0.001)(0-5 \mathrm{~cm}>5-10 \mathrm{~cm}>10-20 \mathrm{~cm})$; there was no similar trend among the $\mathrm{D}, \mathrm{E}$, and $\mathrm{F}$ stages. In the bottom, the CA was greater for deeper soil layers.

\subsection{Correlation between soil water repellency and soil physical and chemical properties}

The results show a significant correlation between CA and soil texture, and CA decreases with sand content increase $(R=-0.885, P<0.001)$. Clay and silt content was positively correlated to soil WR $(R=0.885$, $P<0.001$ ) (Figs. 2e and f). Figure 2a shows a negative correlation relationship between $\mathrm{pH}$ and $\mathrm{CA}$, where as $\mathrm{pH}$ increases, the CA decreases $(R=-0.545, P<0.001)$. The relationship between soil organic carbon content and CA is shown in Fig. 2c. CA increases as organic matter content increases, with a significant linear correlation between them $(R=0.28, \quad P<0.001)$. Figure $2 \mathrm{~b}$ shows the correlation between total $\mathrm{N}$ content and CA. Similarly, CA increases as total $\mathrm{N}$ increases $(R=0.578, \quad P<0.001)$. The linear regression results show that soil total $\mathrm{P}$ content does not alter the CA (Fig. 2d).

Figure 3 shows the linear regression relationship between $\mathrm{CA}$ and eight soluble ions. There are significant positive correlations between $\mathrm{CA}$ and $\mathrm{Cl}^{-}(R=$ $0.507, P<0.001), \mathrm{SO}_{4}{ }^{2-}(R=0.285, P<0.001), \mathrm{Na}^{+}(R=$ $0.462, P<0.001), \mathrm{K}^{+}(R=0.212, P<0.05), \mathrm{Ca}^{2+}(R=$ $0.688, P<0.001), \mathrm{Mg}^{2+}(R=0.411, P<0.001)$, and sig- 
nificant negative correlation between $\mathrm{CA}$ and $\mathrm{CO}_{3}{ }^{2-}$ $(R=-0.378, P<0.001)$. There is no remarkable correlation between $\mathrm{CA}$ and $\mathrm{HCO}_{3}{ }^{-}(R=0.033, P>0.001)$.

According to above-described relationship between $\mathrm{CA}$ and influencing factors, a best-fit general linear model (GLM) model had been established using six variables (sand, clay and silt, $\mathrm{pH}, \mathrm{CO}_{3}{ }^{2-}, \mathrm{Cl}^{-}, \mathrm{SO}_{4}{ }^{2-}$, $\mathrm{Na}^{+}$and total $\mathrm{N}$ ). The results suggested that main influencing factors (soil texture, $\mathrm{pH}, \mathrm{CO}_{3}{ }^{2-}, \mathrm{Cl}^{-}, \mathrm{SO}_{4}{ }^{2-}$, $\mathrm{Na}^{+}$and total N) explained $61.3 \%$ of the overall variation of CA. The GLM regression can be expressed as follows:

$\mathrm{CA}=5.606$ sand +6.496 (clay and silt) $-2.353 \mathrm{pH}+$ $470.089 \mathrm{CO}_{3}{ }^{2-}+11.346 \mathrm{Na}^{+}-1407.707 \mathrm{Cl}^{-}-14.245$ $\mathrm{SO}_{4}{ }^{2-}+0.734$ total N-519.521, $\left(R^{2}=0.613, P<0.001\right)$.
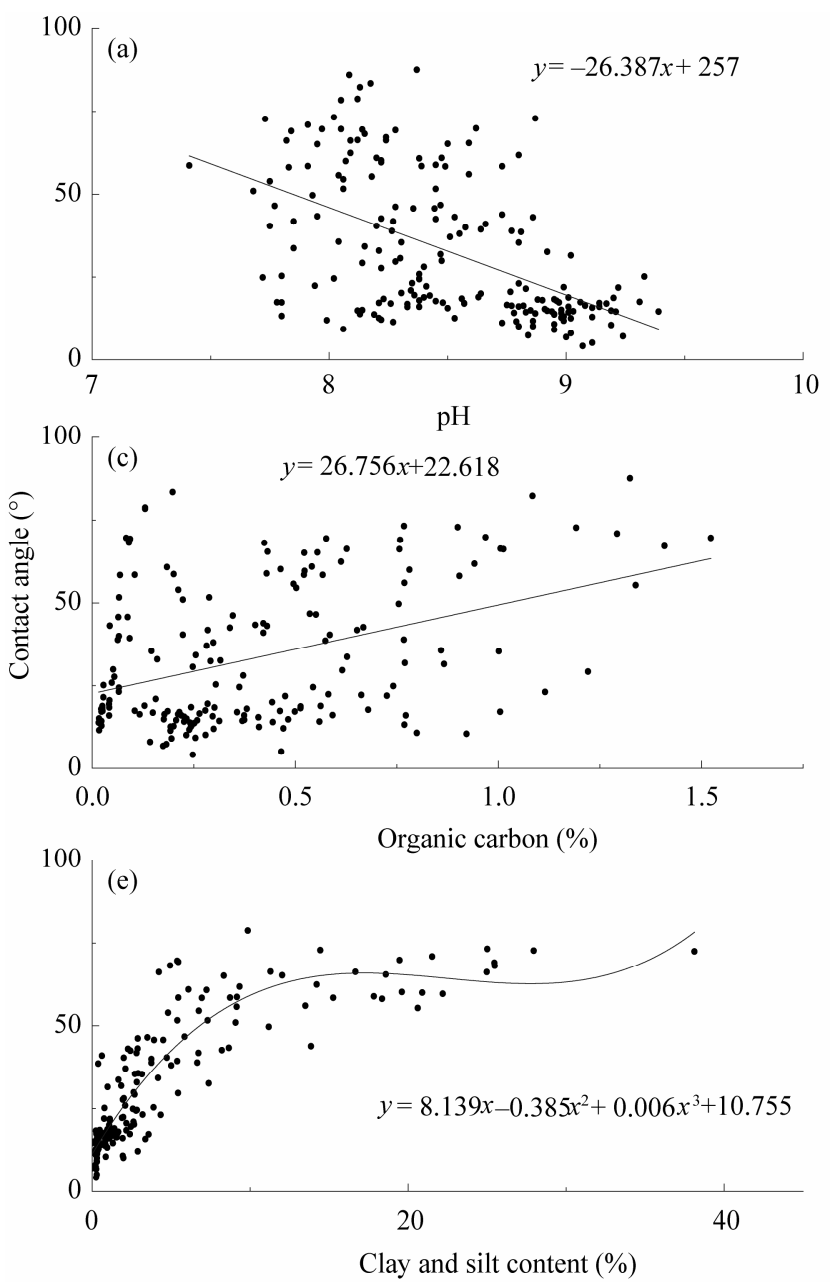

\section{Discussion}

\subsection{Soil WR under different succession stages of Nitraria tangutorun nebkhas}

In general, soil WR is mainly induced by hydrophobic organic matter covering the soil particles and released by roots and plant tissues (Dekker and Ritsema, 1996; Doerr et al., 1998), fungal activity (Jex et al., 1985), or the rates of mineralization and humification (McGhie and Posner, 1981).

Severe soil water repellency (DeBano, 2000; Doerr et al., 2007) is often associated with some vegetations which can secrete resins, waxes or aromatic oils, such as evergreen trees (pines and eucalyptus) (MataixSolera and Doerr, 2004; Hubbert et al., 2006; Lewis et
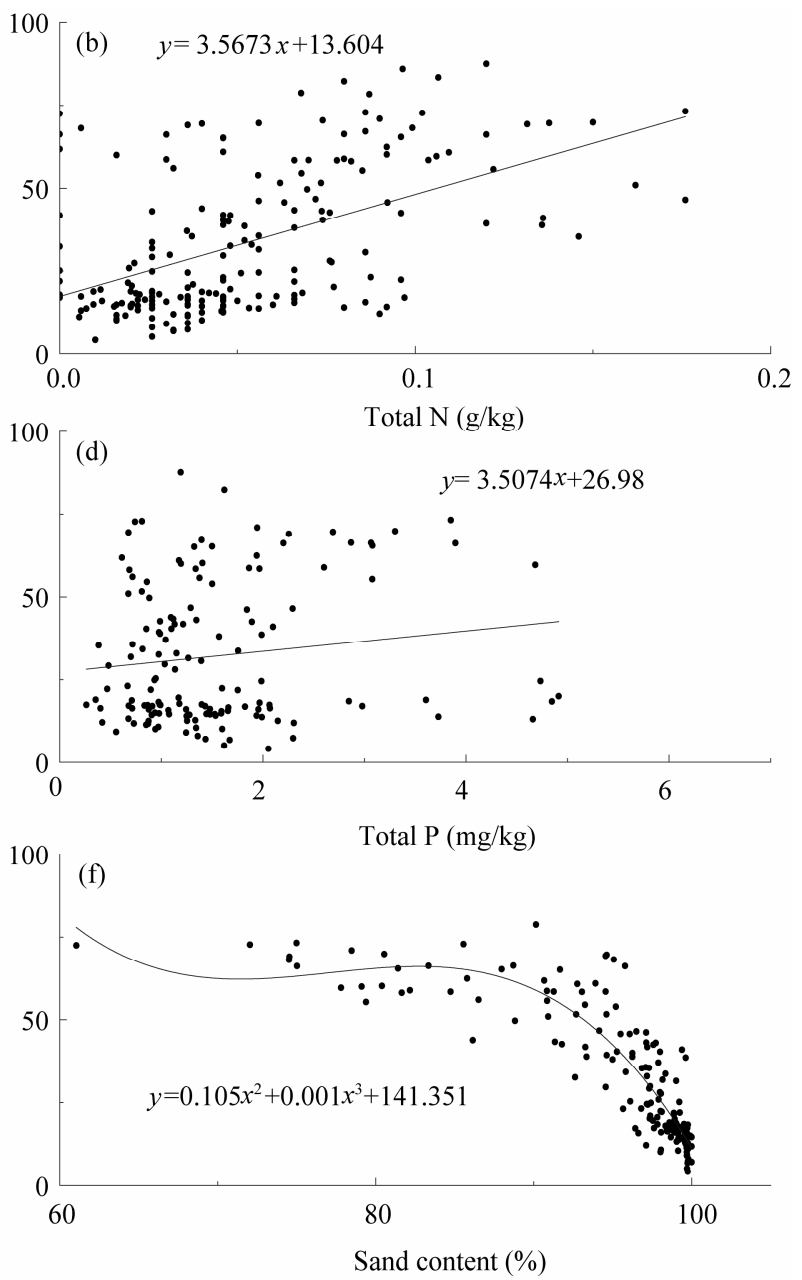

Fig. 2 Relationships between soil water repellency and pH (a), total N (b), organic carbon (c), total P (d), clay and silt content (e), and sand content (f) 

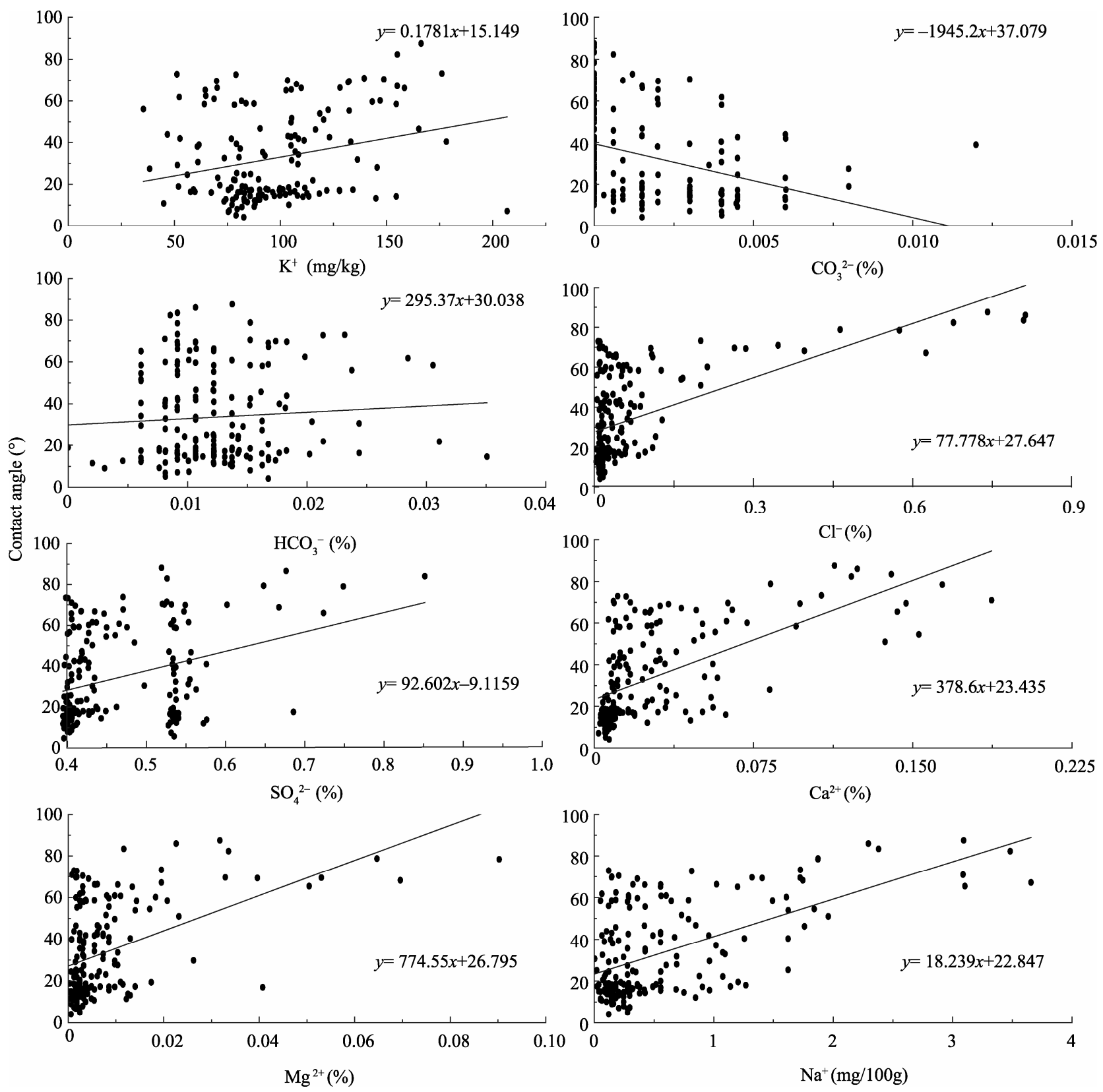

Fig. 3 Relationships between soil soluble ions and soil water repellency

al., 2006), temperate heathlands (Mallik and Rahman, 1985; Jordán et al., 2008) or some Mediterranean shrublands (Giovannini et al., 1987; Mataix-Solera et al., 2007; Jordán et al., 2008). However, in this work, the CA of all soil samples under Nitraria tangutorun are below $90^{\circ}$, therefore all the soil samples are classified as being subcritical WR (slight water repellency). This may be mainly due to one of two reasons. First, the productivity in this area is relatively low due to the dry climatic conditions, as a consequence of a lower input of organic carbon content and the quality of organic matter in the soils. Second, leaves, roots, other Nitraria tangutorun tissues, soil animals and microorganisms secrete a small amount of hydrophobic organic matter which also impacts the soil WR. The results of this study are in accordance with the findings of Varela et al. (2005) who found a lower persistence level of WR in soils under shrubs compared to pine and eucalyptus forests.

This study demonstrates that slight WR in soils varies remarkably among the different succession stages of Nitraria tangutorun nebkhas, due to the fact 
that the development of Nitraria tangutorun nebkhas altered the soil WR characteristics considerably. In addition to the newly developed Nitraria tangutorun nebkhas, the soil WR was significantly increased at other succession stages, the reason for which was the fact that the physical and chemical properties of the newly developed dunes are similar to those of quick sand, therefore the soil WR characteristics of the two dunes are not significantly different. However, as $\mathrm{Ni}$ traria tangutorun nebkhas continues to develop and its surface accumulates a considerable amount of falling dust, branches and leaves are decomposed and stored in the soil, and Nitraria roots secrete a variety of organic substances; consequently, the physical and chemical properties of the soil continuously improve, and the contents of organic matter, total $\mathrm{N}$, clay, and soluble ions increase. Soil organic matter and other substances may modify the surface properties of soil particles by changing the surface tension of the particle surfaces. In this study, these are expected to increase the CA or subcritical WR. It was shown that soil WR at the upper soil layer was significantly greater than that of the lower layers. This is mainly due to the fact that the surface soil accumulates more litter than the lower layers, where organic matter is decomposed. In addition, the biological soil crust which appears during the degradation stage is another important reason for the increase in water repellency. The soil WR of Nitraria tangutorun nebkhas is significantly different at various succession stages, with an increasing trend from the mobile sand dune stage to the newly developed stage, then to the stable developed stage.

Although it is different from severe WR, the term subcritical WR has been introduced for soils which show reduced wettability (Hallett et al., 2001; Czachor et al., 2010). Subcritical WR in soils may inversely alter the hydrological and ecological processes of the dune surface, in ways such as by reducing water infiltration, increasing runoff, and ultimately reducing the supply of water inside the dune; in this manner, surface water redistribution due to soil WR would affect the water usage of Nitraria tangutorun, contributing to the degradation of Nitraria tangutorun nebkhas.

\subsection{Influence of soil characteristics on water re- pellency}

The relationship between severe soil WR and organic carbon content has been appeared in many studies. However, the results remain inconsistent. Some authors have found strong positive correlations between soil organic matter content and severe WR (Varela et al., 2005; Mataix-Solera et al., 2007), while others found a negative or non-correlated relationship between the two factors (Teramura, 1980; DeBano, 1991; Wallis et al., 1993; Ritsema and Dekker, 1994). These discrepancies may be due to the quality of soil organic matter, which is more important than the amount of organic matter in the soil (Doerr et al., 2000). However, beyond this there is little information regarding the relationship of subcritical WR and the organic carbon content in soils. In this study, remarkable positive correlations between the organic carbon content in soils and subcritical WR were determined for soils under Nitraria tangutorun. In contrast with forest and grassland soils, soils under Nitraria tangutorun contain very little hydrophobic organic matter capable of inducing WR. Although organic matter in soils under Nitraria tangutorun may not induce severe WR, it may contribute to subcritical WR.

In this study, strong WR was not found in soils with $\mathrm{pH}$ ranging from 7.41 to 9.39 . The CA of all soils below $90^{\circ}$ was in accordance with the concept that it is more difficult for alkaline soils to produce severe soil WR than acidic soils (Roberts and Carbon, 1971; Benito et al., 2003; Cerdà and Doerr, 2007; Mataix-Solera et al., 2008). The study results also show negative relationships between subcritical WR and $\mathrm{pH}$. It is demonstrated that soil subcritical WR in alkaline soils may be greatly influenced by soil acidity. Subcritical WR decreases with an increasing $\mathrm{pH}$. This is in agreement with previous findings concerning the relationship of the persistence of severe WR and soil acidity (Mataix-Solera et al., 2007). The $\mathrm{pH}$ of the soil may modify the surface properties and structure of the soil and soil organic matter, in turn influencing the WR (De Jonge et al., 1999).

In this study, subcritical WR was found to increase as the clay and silt contents increased and the sand content decreased. The findings of this study agree with those of Zavala (2009), who found that soil WR 
increased in soil samples containing more than $20 \%$ clay. However, this result is not in accordance with the general theory which states that soil WR is more prone to be produced in coarse grained soils than fine grained soils. It is widely believed that coarse textured soils with a low specific surface area are more susceptible to soil WR than fine grained soils with a larger specific surface area (Roberts and Carbon, 1972). This may be due to the fact that the low specific surface area is prone to be covered by a relatively small amount of hydrophobic organic matter (Giovannini and Lucchesi, 1983; Blackwell, 1993), thus more hydrophobic organic matter is required for developed soil WR as the clay content increases. However, most studies in recent years have confirmed that water repellency may occur in clay soils, with some even exhibiting higher degrees of WR (McGhie and Posner, 1980; Dekker and Ritsema, 1996; de Jonge et al., 1999). In this study, the relatively low organic matter from biomass production was not enough to cover all soil particles. However, clay and silt soil from dust fall may contain relatively larger amounts of organic matter. It is speculated that the occurrence of subcritical WR under Nitraria tangutorun may depend on the soil porosity and capillarity. As the clay content increases, the soil porosity may be greatly changed. Therefore, soil capillarity is modified to contribute to subcritical WR.

Few studies regarding the relationship between total $\mathrm{N}$ and soil subcritical WR have been performed in the past. This study shows that there is a significantly positive correlation between total $\mathrm{N}$ and soil subcritical WR. It is concluded that total $\mathrm{N}$ contributes to the formation of soil subcritical WR.

The relationship between CA and soluble ions depends on the type of ions. $\mathrm{Cl}^{-}, \mathrm{SO}_{4}{ }^{2-}, \mathrm{Na}^{+}, \mathrm{K}^{+}, \mathrm{Ca}^{2+}$ and $\mathrm{Mg}^{2+}$ can significantly promote the formation of soil subcritical WR (Fig. 3). These cations may be adsorbed on the surface of the soil particles, and the CA may increase as the number of adsorbed ions increases. However, $\mathrm{CO}_{3}{ }^{2-}$ is not conducive to the formation of soil subcritical WR. This is mainly due to the fact that $\mathrm{CO}_{3}{ }^{2-}$ ions are able to easily react with $\mathrm{Ca}^{2+}$ and $\mathrm{Mg}^{2+}$ ions to form insoluble substances such as $\mathrm{CaCO}_{3}$ and $\mathrm{MgCO}_{3}$, which may have greater surface tensions, thus effectively reducing the $\mathrm{CA}$ and soil subcritical WR. $\mathrm{HCO}_{3}{ }^{-}$does not affect the change of $\mathrm{CA}$ and soil subcritical WR.

Finally, the best GLM model shows the contribution of main influencing factors on soil subcritical WR. This model can be used to effectively predict CA and soil subcritical WR.

\section{Conclusion}

In this study it was concluded that all soils under $\mathrm{Ni}$ traria tangutorun nebkhas contain subcritical WR. The development and succession of $N$. tangutorun nebkhas may improve soil subcritical WR, which is shown by the fact that the soil WR of newly developed $N$. tangutorun nebkhas is similar to that of mobile sand dune, increasing as nebkha develops and reaching the highest point at the extremely degraded stage. On the other hand, soil subcritical WR may affect the hydrological process of $N$. tangutorun nebkhas, promoting the degradation of sand dunes. There was little information of relationships between soil subcritical WR and soil physical or chemical properties. On the basis of our results, significant relationships have been established between them. Soil organic matter, total $\mathrm{N}$ content, clay and silt, $\mathrm{Ca}^{2+}, \mathrm{Mg}^{2+}$, $\mathrm{K}^{+}, \mathrm{Na}^{+}, \mathrm{Cl}^{-}$and $\mathrm{SO}_{4}{ }^{2-}$ play a crucial role in the development of soil subcritical WR. However, high $\mathrm{pH}$, sand content and $\mathrm{CO}_{3}{ }^{2-}$ may prevent the formation of soil subcritical WR. We also found a best GLM model between influencing factors and soil subcritical WR. Given the information, one can predict the CA of all soils exhibiting subcritical WR, and there may be particular management implications for the succession of this $N$. tangutorun nebkhas under human intervention.

\section{Acknowledgements}

This research was supported by the National Basic Research Program of China (2009CB421303), the Strategic Priority Research Program-Climate Change: Carbon Budget and Relevant Issues of the Chinese Academy of Sciences (XDA05050406-1), and the National Natural Science Foundation of China (40930636, 41240003, 41271061).

\section{References}

Barnes R B, Richardson D, Berry J W, et al. 1945. Flame photometry a rapid analytical procedure. Industrial \& Engineering Chemistry Analytical Edition, 17(10): 605-611.

Bauters T W J, DiCarlo D A, Steenhuis T S, et al. 1998. Preferential flow 
in water-repellent sands. Soil Science Society of America Journal, 62: $1185-1190$

Benito E, Santiago J L, de Blas E, et al. 2003. Deforestation of water-repellent soils in Galicia (NW Spain): effects on surface runoff and erosion under simulated rainfall. Earth Surface Processes and Landforms, 28: 145-155.

Berglund K, Persson L. 1996. Water repellence of cultivated organic soils. Acta Agriculturae Scandinavica, 46: 145-152.

Blackwell P S. 1993. Improving sustainable production from water repellent sands. Western Australia Journal of Agriculture, 34: 160-167.

Blanco-Canqui H, Lal R, Shipitalo M J. 2007. Aggregate disintegration and wettability for long-term management systems in the northern Appalachians. Soil Science Society of America Journal, 71: 759-765.

Blanco-Canqui H, Lal R. 2009. Extent of soil water repellency under long-term no-till soils. Geoderma, 149(1-2): 171-180.

Cann M A. 2000. Clay spreading on water repellent sands in the south east of South Australia-promoting sustainable agriculture. Journal of Hydrology, 231-232: 333-341.

Cerdà A, Doerr S H. 2007. Soil wettability, runoff and erodibility of major dry-Mediterranean land use types on calcareous soils. Hydrological Processes, 21(17): 2325-2336.

Cosentino D, Hallett P D, Michel J C, et al. 2010. Do different methods for measuring the hydrophobicity of soil aggregates give the same trends in soil amended with residue? Geoderma, 159(1-2): 221-227.

Czachor H, Doerr S H, Lichner L. 2010. Water retention of repellent and subcritical repellent soils: New insights from model and experimental investigations. Journal of Hydrology, 380(1-2): 104-111.

DeBano L F. 1991. The effects of fire on soil properties. United States Department of Agriculture, Forest Service. General Technical Report, 280: 151-156.

DeBano L F. 2000. Water repellency in soils: a historical overview. Journal of Hydrology, 4-32.

De Jonge L W, Jacobsen O H, Moldrup P. 1999. Soil water repellency: effects of water content, temperature and particle size. Soil Science Society of America Journal, 63: 437-442.

Dekker L W, Ritsema C J. 1994. How water moves in a water repellent sandy soil. 1. Potential and actual water repellency. Water Resources Research, 30: 2507-2517.

Dekker L W, Ritsema C J. 1996. Preferential flow paths in a water repellent clay soil with grass cover. Water Resources Research, 32: 1239-1249.

Dekker L W, Oostindie K, Ritsema C J. 2005. Exponential increase of publications related to soil water repellency. Australian Journal of Soil Research, 43: 403-441.

Dick W, Tabatabai M. 1979. Ion chromatographic determination of sulfate and nitrate in soils. Soil Science Society of America Journal, 43(5): 899-904.

Doerr S H. 1998. On standardizing the 'water drop penetration time' and the 'molarity of an ethanol droplet' techniques to classify soil hydrophobicity: a case study using medium textured soils. Earth Surface Processes and Landforms, 23: 663-668.

Doerr S H, Shakesby R A, Walsh R P D. 1998. Spatial variability of soil hydrophobicity in fire-prone eucalyptus and pine forests, Portugal. Soil Science, 163: 313-324.

Doerr S H, Shakesby R A, Walsh R P D. 2000. Soil water repellency: its causes, characteristics and hydro-geomorphological significance. Earth-Science Reviews, 51: 33-35.

Doerr S H, Llewellyn C T, Douglas P, et al. 2005. Extraction of compounds associated with water repellency in sandy soils of different origin. Australian Journal of Soil Research, 43: 225-237.

Doerr S H, Ritsema C J, Dekker L W, et al. 2007. Water repellence of soils: new insights and emerging research needs. Hydrological Processes, 21: 2223-2228.

Giovannini G, Lucchesi S. 1983. Effect of fire on hydrophobic and cementing substances of soil aggregates. Soil Science, 136: 231-236.

Giovannini G, Lucchesi S, Cervelly S. 1987. The natural evolution of a burnt soil: a 3 year investigation. Soil Science, 143: 220-226.

Hadjiioannou T, Papastathopoulous D. 1970. EDTA titration of calcium and magnesium with a calcium-selective electrode. Talanta, 17(5): 399-406.

Hallett P D, Baumgartl T, Young I M. 2001. Subcritical water repellency of aggregates from a range of soil management practices. Soil Science Society of America Journal, 65: 184-190.

Han F G, Han S H, Chang Z, et al. 2008. Study on characteristics and variance tendency of the main climatic factors in Minqin Desert area in recent 46 years. Journal of Arid Land Resources and Environment, 22(11): 45-49.

Horne D J, McIntosh J C. 2000. Hydrophobic compounds in sands in New Zealand; extraction, characterization and proposed mechanisms for repellency expression. Journal of Hydrology, 231-232: 35-46.

Hubbert K R, Preisler H K, Wohlgemuth P M, et al. 2006. Prescribed burning effects on soil physical properties and soil water repellency in a steep chaparral watershed, southern California, USA. Geoderma, 130: 284-298.

Jaramillo J D F, Dekker L W, Ritsema C J, et al. 2000. Occurrence of soil water repellency in arid and humid climates. Journal of Hydrology, 231-232: 105-111.

Jex G W, Bleakley B H, Hubbell D H, et al. 1985. High humidity-induced increase in water repellency in some sandy soils. Soil Science Society of America Journal, 49: 1177-1182.

Jordán A, Martínez-Zavala L, Bellinfante N. 2008. Heterogeneity in soil hydrological response from different land cover types in southern Spain. Catena, 74: 137-143.

Jordán A, Zavala L M, Mataix-Solera J, et al. 2013. Soil water repellency: origin, assessment and geomorphological consequences. Catena, 108: 1-5.

Ramírez-Flores J C, Woche S K, Bachmann J, et al. 2008. Comparing capillary rise contact angle of soil aggregates and homogenized soil. Geoderma, 146: 336-343.

Letey J. 1969. Measurement of contact angle, water drop penetration time, and critical surface tension. In: DeBano L F, Letey J. Proceedings of a Symposium on Water Repellent Soils, 6-10 May 1969, Riverside: University of California.

Lewis S A, Wu J Q, Robichaud P R. 2006. Assessing burn severity and comparing soil water repellency, Hayman Fire, Colorado. Hydrological Processes, 20: 1-16. 
Li X J, Li X R, Song W M, et al. 2008. Effects of crust and shrub patches on runoff, sedimentation, and related nutrient $(\mathrm{C}, \mathrm{N})$ redistribution in the desertified steppe zone of the Tengger Desert, Northern China. Geomorphology, 96: 221-232.

Lin C Y, Chou W C, Tsai J S, et al. 2006. Water repellency of Casuarina windbreaks (Casuarina equisetifolia Forst.) caused by fungi in central Taiwan. Ecological Engineering, 26: 283-292.

Mallik A U, Rahman A A. 1985. Soil water repellency in regularly burned Calluna heathlands: comparison of three measuring techniques. Journal of Environmental Management, 20: 207-218.

Martínez-Zavala L, Jordán-López A. 2009. Influence of different plant species on water repellency in Mediterranean heathland soils. Catena, 76(3): 215-223.

Mataix-Solera J, Doerr S H. 2004. Hydrophobicity and aggregate stability in calcareous topsoils from fire-affected pine forest in the south-east of Spain. Geoderma, 118: 77-88.

Mataix-Solera J, Arcenegui V, Guerrero C, et al. 2007. Water repellency under different plant species in a calcareous forest soil in a semiarid Mediterranean environment. Hydrological Processes, 21 (17): 2300-2309.

Mataix-Solera J, Arcenegui V, Guerrero C, et al. 2008. Can terra rossa become water repellent by burning? A laboratory approach. Geoderma, 147: 178-184.

Mataix-Solera J, Cerdà A, Arcenegui V, et al. 2011. Fire effects on soil aggregation: a review. Earth-Science Reviews, 109(1): 44-60.

McGhie D A, Posner A M. 1980. Water repellence of heavy textured western Australian surface soil. Australian Journal of Soil Research, 18: 309-323.

McGhie D A, Posner M A. 1981. The effect of plant top material on thewater repellence of fired sands and water-repellent soils. Australian Journal of Agricultural Research, 32: 609-620.

McKissock I, Gilkes R J, Van Bronswijk W. 2003. The relationship of soil water repellency to aliphatic $\mathrm{C}$ and kaolin measured using DRIFT. Australian Journal of Soil Research, 41: 251-265.

McLeod M, Aislabie J, Smith J, et al. 2001. Viral and chemical tracer movement through contrasting soils. Journal of Environmental Quality, 30: 2134-2140.

Morrow N R. 1976. Capillary-pressure correlations for uniformly wetted porous-media. Journal of Canadian Petroleum Technology, 15: 49-69.

Ortega A, Lorite J. 2007. Macrofungi diversity in cork-oak and holm-oak forests in Andalusia (southern Spain); an efficient parameter for establishing priorities for its evaluation and conservation. Central European Journal of Biology, 2: 276-296.

Park D M, Cisar J L, Williams K E, et al. 2004. Alleviation of soil water repellency in sand based Bermudagrass in South Florida. Acta Horticulturae, 661: 111-115.

Parkinson J A, Allen S E. 1975. A wet oxidation procedure suitable for determination of nitrogen and mineral nutrients in biological material Commun. Communications in Soil Science and Plant Analysis, 6: $1-11$.

Paul E A, Clark F E. 1996. Soil Microbiology and Biochemistry. New York: Academic Press, 340.
Quyum A. 2001. Moisture movement through hydrophobic soils. MSc Thesis, Calgary: University of Calgary.

Ramírez-Flores J C, Bachmann J, Marmur A. 2010. Direct determination of contact angles of model soils in comparison with wettability characterization by capillary rise. Journal of Hydrology, 382(1-4): $10-19$.

Ritsema C J, Dekker L W. 1994. How water moves in a water repellent sandy soil: 2. Dynamics of fingered flow. Water Resources Research, 30: 2519-2531.

Ritsema C J, Dekker L W. 1998. Three dimensional patterns of moisture, water repellency, bromide and $\mathrm{pH}$ in a sandy soil. Journal of Contaminant Hydrology, 31: 295-313.

Ritsema C J, Dekker L W. 2000. Preferential flow in water repellent sandy soils: principles and modeling implications. Journal of Hydrology, 231-232: 308-319.

Roberts F J, Carbon B A. 1971. Water repellence in sandy soils of southwestern Australia. I. Some studies related to field occurrence. CSIRO (Australia) Division of Plant Industry. Field Station Record, 10: 13-20.

Roberts F J, Carbon B A. 1972. Water repellence in sandy soils of southwestern Australia. II. Some chemical characteristics of hydrophobic skins. Australian Journal of Soil Research, 10(1): 35-42.

Shi J L. 2000. A case study of Minqin Oasis in China. Water International, 25(3): 418-424.

Shirtcliffe N J, McHale G, Newton M I, et al. 2006. Critical conditions for the wetting of soils. Applied Physics Letters, 89(9): 094101094101-3.

Siebold A, Walliser A, Nardin M, et al. 1997. Capillary rise for thermodynamic characterization of solid particle surface. Journal of Colloid and Interface Science, 186: 60-70.

Steenhuis T S, Rivera J C, Hernández C J M, et al. 2001. Water repellency in New York state soils. International Turfgrass Society Research Journal, 9: 624-628.

Teramura H A. 1980. Relationship between stand age and water repellency of chaparral soils. Bulletin of the Torrey Botanical Club, 104: 42-46.

Varela M E, Benito E, de Blas E. 2005. Impact of wildfires on surface water repellency in soils of northwest Spain. Hydrological Processes, 19: 3649-3657.

Walkley A, Black I A. 1934. An examination of the Degtjareff method for determining soil organic matter, and a proposed modification of the chromic acid titration method. Soil Science, 37(1): 29-38.

Wallis M G, Horne D J. 1992. Soil water repellency. Advances in Soil Science, 20: 91-146.

Wallis M G, Horne D J, Palmer A S. 1993. Water repellency in a New Zealand development sequence of yellow-brown sands. Australian Journal of Soil Research, 31: 641-645.

Yang X F, Xi T. 1995. Critical wetting angle for spontaneous liquid infiltration into orderly packed fibres or spheres. Journal of Materials Science, 30: 5099-5102.

Zavala L M, González F A, Jordán A. 2009. Intensity and persistence of water repellency in relation to vegetation types and soil parameters in Mediterranean SW Spain. Geoderma, 152(3-4): 361-374. 